\title{
Flying Fox: Kin, Keystone, Kontaminant
}

\author{
Deborah Bird Rose
}

\begin{abstract}
A portrait of Australian flying fox life in the Anthropocene illuminates startlingly familiar stories. These animals are participants in most of the major catastrophic events, as well as contestations about rescue, of contemporary life on Earth: warfare, man-made mass death, famine, urbanisation, emerging diseases, climate change, biosecurity, conservation and local/international NGO aid. They are endangered, and are involved in all four of the major factors causing extinctions: habitat loss, overexploitation, introduced species and extinction cascades. My account of flying foxes in Australia rests on the understanding of species articulated vigorously and eloquently by Donna Haraway (42): we and others are entangled in knots of species who are co-shaping each other in layers of reciprocating complexity. I seek to engage both the living warmblooded beings whose lives are threatened and the excruciatingly dynamic deathscape that is surrounding them/us. Positioned, like much of life on Earth today, in zones of increasing conflict and terror, the lives and deaths of flying foxes tell us that there is no way out of entanglements within multi-species communities. Rather than seeking to erect more impenetrable barriers against others, relational ethics for living and dying in the Anthropocene urge us to assume ever greater mutuality and accountability as intra-dependent members of the suffering family of life on Earth.
\end{abstract}

\section{Sociability, flying fox style $\sim$ Megachiroptera}

Australian megachiroptera scrabbled into the English imagination in June 1770 when Captain Cook anchored his ship Endeavour at the mouth of a river in Queensland for repairs. One of his men returned to camp telling of an animal he had seen: 'It was as black as the devil and had wings; indeed I took it for the devil, or I might easily have catched it for it crawled very slowly through the grass' (qtd in Ratcliffe, Flying Fox and Drifting Sand 6). We might imagine that something was wrong with the little guy, as flying foxes can't walk and wouldn't normally be crawling in the grass. One wonders if the seaman had thrown stones at it, but perhaps it is equally possible to imagine that the flying fox, never having seen a white man before, was reeling with shock. They are alert creatures, extremely aware of what is going on around them. Pamela Conder, a recent student of flying foxes, writes of her time sitting quietly inside a flying fox enclosure in a wildlife sanctuary observing their actions and interactions. 
She says that the flying foxes quickly became accustomed to her, regarding her, apparently, as an innocuous part of the background. However, 'I was surprised when I walked into the cage late one hot morning to see the bats panic and flee in all directions from my approach. Then I realised what was different-I was wearing a large sun hat. I left the enclosure, let the bats settle and returned sans hat. Not so much as an eyebrow was raised. Before long, however, the hat became accepted as part of me for the rest of that summer' (55).

The term chiroptera means 'hand winged'. There are two suborders: mega and micro. Worldwide, megachiroptera include 166 species of flying foxes (also known as fruit bats) and blossom bats. Microchiroptera include 759 species. The two suborders are quite different, size being only part of it. Microchiroptera navigate by echolocation (animal sonar); they are small and feed mainly on insects but there also are blood-eating vampire bats, fish-eating bats and other carnivorous bats. In contrast, Megachiroptera all feed on plants. They navigate principally by sight, and many of them are large. In Australia, the largest male flying foxes weigh about one kilogram and have wingspans of up to 1.5 metres (Hall and Richards 1-3). There is no way of knowing the flying fox population figures prior to British settlement, but certainly the numbers would have been in the thousands of millions. Four main species of flying foxes make up the Australian contingent: Black Flying Fox (Pteropus Alecto), Grey-headed Flying Fox (P. poliocephalus), Little Red Flying Fox ( $P$. scapulatus), and Spectacled Flying Fox ( $P$. conspicillatus). By preference they travel widely in search of pollen, seeds and fruits, covering vast areas during an annual round as they follow flowering and fruiting trees and shrubs. At present, both grey-headed and spectacled flying foxes are listed as threatened under the Commonwealth Environment Protection and Biodiversity Conservation Act 1999.

Flying foxes love to camp together; some camps number in the millions (Conder 46). Maternity camps are chosen by the female flying foxes, and they return year after year to give birth and raise their young. Every night across Australia millions of flying foxes set forth, going distances of up to fifty kilometres in search of food. It is estimated that one individual can disperse up to 60,000 seeds in one night (DSE 4). They are sociable, spending much of their time in camp grooming themselves and each other. With at least thirty different vocal calls, all of which are audible to humans, they are, from a human point of view, noisy folk (Hall and Richards 64). Females give birth to only one baby each year. Babies are born with their eyes open, and their mother gently moves them into position so that they can latch on to her nipple. For a few weeks they hang on while she flies out at night for food. Later, though, they are left behind in crèches in the centre of camp. The mothers return at dawn, flying round and round until they locate their own baby, re-attaching the baby to the nipple. Once the babies have grown into adolescents or young adults, they leave their 
mothers and move into groups under the care of senior males. The older guys take them out at night, teaching them flying techniques, and showing them how to find food and find their way home again (Hall and Richards 42-46). Hall and Richards (46) describe these clumsy youngsters:

They do not have the purposeful direction of the adults, and are reminiscent of a group of school kids going home from school and exploring their environment. Progress is slow as they carry out aerial bombs on each other, explore vegetation and duck from imaginary predators. It is probable that these groups do not initially go far from the camp, and that the trips serve as navigational training.

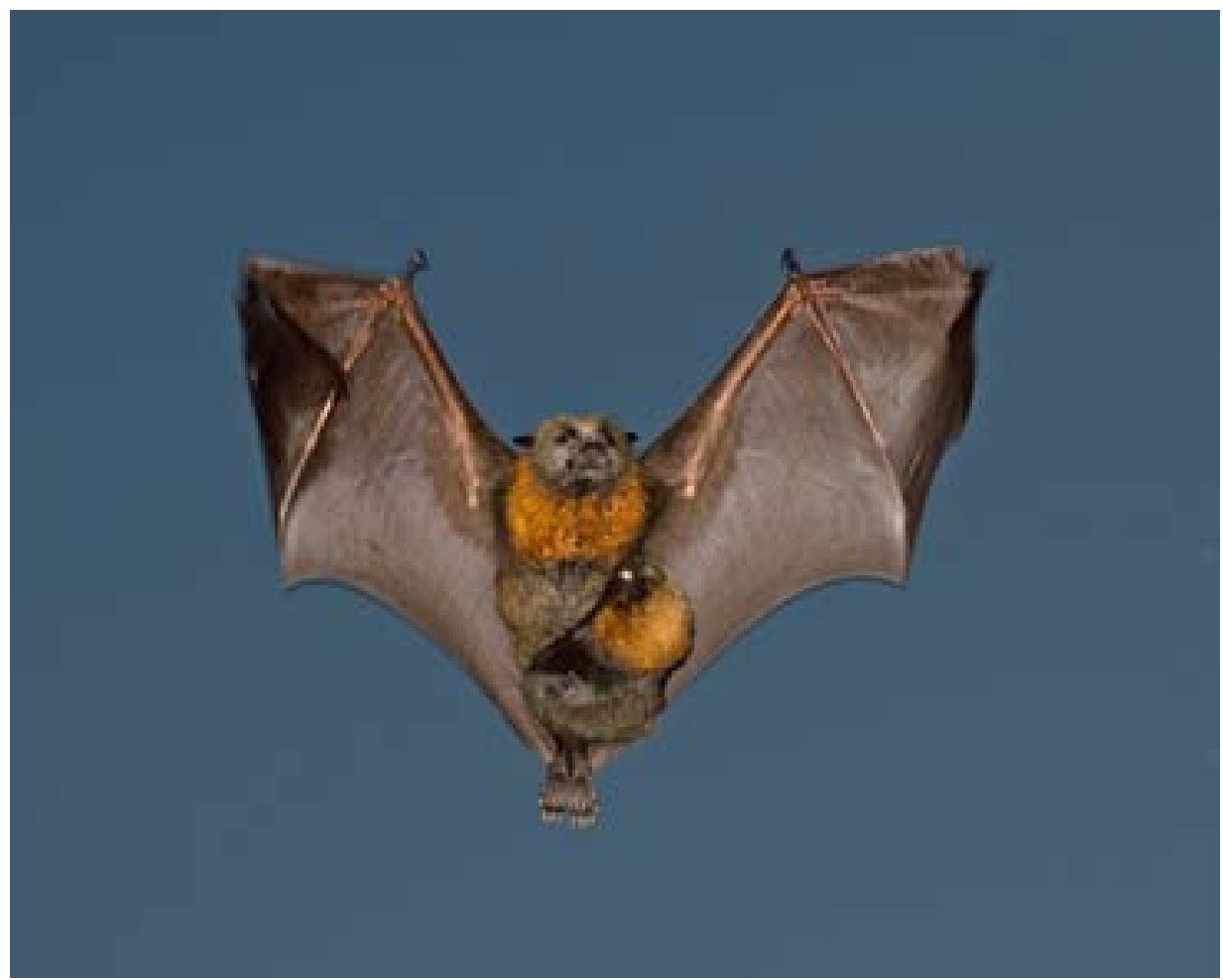

"For the first few weeks of life, the new born pups stay with their mothers 24 hours a day, even as she flies out to forage for food. Once the pups reach around 4 weeks of age, they're too heavy for their mothers to carry them for long distances but she may still carry them for between trees in the roost. It's important to remember that whilst in flight, the mother is in no way actively holding the pup to her chest, it's only the young ones grip on their mothers teat (located under her armpit") and fur that keep them from falling" (Photo and caption courtesy of Nick Edards). 


\section{Story-telling, Indigenous style}

Flying foxes had been interacting with humans for thousands of years before they encountered either Englishmen or large summer hats. Indigenous people's stories of flying foxes go back to creation, to the Dreaming ancestors who walked the earth making landforms, species, cultures, languages, biotic communities and connections. Dreamings were shape-shifters, sometimes walking as humans, sometimes travelling in the form of the being they would become. Flying foxes were there too, of course.

I got to know flying foxes through Indigenous people of the Victoria River region in the northwest corner of the Northern Territory, where I lived and studied for many years in the communities of Yarralin and Lingara. Prior to the wet season (in December or so), the black flying foxes, warrpa in local languages, congregated along the riverbanks, hanging from the riverside trees. Occasionally one might lose its grip and become a tasty treat for crocodiles. Of an evening we would watch them fly out, dark against the deep blue sky, hundreds upon hundreds of them forming a stream of flapping wings that widened out as they moved toward the flowering trees along the rivers and creeks. One of my teachers was Daly Pulkara, a man with a good fund of flying fox stories. We were watching the flyout one evening, and he pointed out something interesting. The crowd flew over, and then, after the mob was well on its way, a few turned back. A bit later, stragglers appeared, following the others but not quite catching up. 'The old people always said those blokes forgot their axes', Daly told me. I felt like a bit of a straggler myself as I tried to catch the drift of the story. Of course, they were shape-shifters, and when they were men they would have carried axes. 'They're always like that', Daly said, 'one or two are back behind. That's why the old people said they forgot their axes, they had to go back to camp and get them'.

To encounter such stories in their wonderful personableness and appropriateness is to find one's self in a world of animism. Defined and discussed in a new and excellent study by Graham Harvey, animism is the recognition 'that the world is full of persons, only some of whom are human, and that life is always lived in relationship with others' (xi). Within an animist worldview, flying foxes are persons, and like any group of human persons some are a bit sloppy, forgetting their axes when they go out foraging, dragging along behind, always a bit out of step.

The personhood of flying foxes is known not only through stories but also through kinship. Flying foxes are matrilineal 'totems': they are members of kin groups comprised of both human and flying fox persons. Flying foxes are part of the group by reason of being flying foxes. Humans are part of the group because their mother, and her mother, and her mother, right back to the beginning, 
were flying fox people. Men belong to the group - they are flying fox people because they are the children of their mother, but their sons and daughters will not be flying foxes because flying fox people don't marry other flying fox people. The matrilineal kin relationship is understood to be corporeal- the flesh of the kin group is shared across the bodies of the people and animals, and is their co-specific embodied being in the world. This is the family: humans and nonhumans. They are in it together, sharing flesh, care and continuity from generation to generation.

Flying fox persons (animal/human) are also part of the story of seasons. Why does the rain come? My teachers said that it comes because the flying foxes tell the Rainbow Snake to get up out of the river and get to work. This is a complex story of entangled mutualities and calls to action. The story of rain starts in the dry season, during the cold time of year when the flying foxes are in the higher country away from the rivers. As the sun dries the country, they move toward the river, and when they get there they hang in the trees over the river and call to the Rainbow Snake to rise up and bring rain. A lot of esoteric knowledge is bound into this story; we will avoid that knowledge completely, and turn to an ecological side of the story. Flying foxes feed by preference on the flowers of trees and shrubs of the Myrtaceae family. Yarralin people point especially to the inland bloodwood (Eucalyptus terminalis, jartpuru in local languages) and the magnificent tree known in vernacular English as the half bark (E. Confertiflora, ngurlgugu). Both of these species produce large, showy clusters of cream-coloured, heavily scented flowers, so they are obvious candidates for both flying fox and human attention. In the Victoria River region eucalypts and melaleucas flower in succession from higher ground to lower ground, which is also to say from the drier country on the hillsides down to the river banks and channels. River red gum (E. Camaldulensis), known as timalan in local Indigenous languages, and paperbarks (pakali, Melaleuca argenta and $M$. leucadendra) are the two big riverside Myrtaceous trees. The banks of the rivers of this region are lined with paperbarks and river red gums. They are the last in the succession to burst into flower. The flying foxes follow their preferred food, and it brings them to the riverside at the end of the driest time of year; they forage there in the thousands. Yarralin people say that the flying foxes talk to their mate the Rainbow, telling it to move, to get up, to get to work, to bring the rain. They say that the earth is getting too hot, that everything is too dry.

\section{Co-evolution, a myrtaceous love affair}

Flying foxes have been relating to native trees for much longer than they have been relating to humans. According to Hall and Richards (82-84), there is good evidence to support a hypothesis of co-evolution and co-dependence between megachiropterans and flowing plants. In fact, flying foxes and the smaller tube- 
nosed fruit bats may be the only seed dispersal agents for many rainforest trees, and therefore are integral to the long-term survival of some species (Hall and Richards 83). Flying foxes have a keen sense of smell and their eyes are adjusted to night vision and to recognising light colours. Myrtaceous trees and shrubs produce clumps of flowers that are strongly scented and usually light in colour. They produce their pollen in the night, when the flying foxes are foraging; flying foxes are able to carry large loads of pollen because of their (relatively) large size; and because the plants flower sequentially, 'myrtaceous forests and woodlands provide a constant food supply throughout the year for these animals' (Hall and Richards 82).

Seed and pollen dispersal is improved by flying fox feeding habits. In scientific lingo, people talk about the 'residents and raiders' model of feeding. A group settles itself into a tree and then defends that place from others: these are the 'residents'. Other flying foxes attempt to join the group: these are the 'raiders'. Residents chase them away. They carry fruit and pollen from tree to tree as they struggle to find a place to stay and feed (Hall and Richards 81-82). The stragglers that Daly spoke about - the blokes who always forget their axes - would seem to be 'raiders': having gone back to get their axes they now find the best food locations already taken. They may be a bit on the edge, but they are extremely important to Myrtaceae.

Scientific studies of flying fox feeding and their relationships with their preferred species have led to the understanding that flying foxes are a keystone species: as long-range pollinators and seed dispersers, their activities are essential to the health of native ecosystems. Indeed, as climate change forces species to adapt rapidly, flying foxes will become increasingly important in maintaining gene flow and thus facilitating adaptation (Booth et al. 4-5). As the populations of flying foxes are in rapid decline, there is the possibility that some species in some areas may become functionally extinct within a few decades (Booth et al. 5). Functional extinction precedes actual extinction; it is a loss of connectivity and mutuality. Lose the flying foxes and there's no way of knowing just how far the unravelling of life systems will go.

\section{Kinship, scientific style}

Co-evolution is a process of mutual convergence by which entirely separate species evolve to mutual advantage. In contrast, linear evolution is imagined as the diversification of species who are descended from a common (albeit often extremely distant) ancestor. The differences between megachiroptera and microchiroptera are well established, but what is their origin, from an evolutionary point of view? Did flying foxes and bats have separate origins, and converge in shape for reasons of adaptation to flying? Or did they have a 
common ancestor, and did they therefore diverge as they adapted to different environments and conditions? Queensland neurologist John Pettigrew proposes the first alternative. He was performing what he calls a 'routine investigation' on the inner workings of a flying fox brain and was astonished to discover that it was identical in many key features to the brains of primates: 'Primates share a half-dozen brain pathways not found in any of the other 20 mammalian orders. These features are quantitative and are believed to reliably distinguish primates from non-primates. They provide a unique signature, enabling us to recognize a primate brain after a set of tests which involve labelling the pathways going from the eye to the brain' (Pettigrew). This analysis suggests that flying foxes are small primates who took to the airways. According to Pettigrew, 'under the microscope the affinities between megabat and lemur brains are so striking that it is quite difficult to tell them apart. So far as one can tell from the intricate details of the wiring of thousands of nerve cells, primates and megabats shared a common ancestor not shared by any other group of mammals'. Pettigrew's analysis is debated, and at the moment the issue is open.

When I first heard about this research I became quite excited. During my years in Aboriginal communities I had, of course, encountered many flying foxes, mostly as food. A close encounter with a flying fox induces the strong awareness of being in the company of an odd little kinsman. With their small furry bodies and dog/human-like faces; with their chattery camps full of individuals who are grooming each other and carrying on their daily life - mating, raising babies, guarding teenagers, remaining attentive to sources of food in the region; with their fantastic wing-spread and their spectacular nightly flyouts, I find it difficult to understand how anyone could fail to be completely entranced.

Understandably, perhaps, when they decide to camp in suburban back yards, coming in by the thousands and showing no inclination to move on as long as there is food in the region, humans do lose patience. I can't help but think that something about them reminds us of us - of how we are when we are at our most crowded, noisy and irritating.

\section{Shadow of Death}

In addition to the distaste some people experience toward the bat shape and the bat reputation, and to the smell and the noise, orchardists have a grievance against flying foxes who eat the fruit. Although the evidence is clear that flying foxes prefer the myrtaceae flowers and forest fruits with which they are coevolved, the clearing of native vegetation and its replacement with commercial fruit crops has left them little choice. Biologist Francis Ratcliffe came out to Australia in 1929 sponsored by the state governments of New South Wales and Queensland to investigate the orchardists' problem. He was asked to provide 
information on flying foxes; the desire amongst many orchardists was less for information than for quick measures for eradicating flying foxes. Orchardists, along with many other people, held what we might call a zero-tolerance vision. Basically, they wanted flying foxes gone forever. This is an 'us' and 'them' boundary organised along an either-or axis: it offers no place for co-existence or mutuality. Ratcliffe's research led him to the conclusion that total eradication of flying foxes was impossible. He concluded that while it would be well-nigh impossible to eradicate flying foxes quickly, their populations seemed to be in fairly rapid decline; it thus seemed possible that the problem would take care of itself (Flying Fox and Drifting Sand 10).

The story of how several species of flying foxes were tipped to the point of being declared threatened species is a story of the Anthropocene. All the factors arise out of human action, but not all factors are directly intended to eliminate flying foxes. Martin and McIlwee sum them up: 'habitat destruction, persecution and culling' (98). In a subsequent list they add climate change. Bearing in mind that habitat clearance has removed vast amounts of myrtaceous woodland, leaving flying foxes with very little choice but to turn toward the commercial orchards with which farmers have replaced native vegetation, let us look first at a number of indirect factors.

Habitat clearance has effects that go beyond pushing flying foxes toward orchards. One is to increase the distances between native food sources to the point where flying foxes can no longer make it from one area to the next. Populations that become hemmed in are effectively trapped, and completely dependent on local foods (Conder 50), leading to mass starvation. In 2006 the Bat Rescue online newsletter carried an article on mass starvation in Queensland:

The combination of unusually low winter temperatures and shortage of food has been blamed for the large numbers of flying foxes found dead or dying along much of the East Coast during the last few weeks. With their lower fat reserves and inability to fly greater distances in search of food, juveniles have been particularly hardest hit. ... A number of bats have become entangled in backyard fruit tree netting ... some have fallen victim to dogs or hit by cars and others have simply been found hanging dead or dying very low to the ground. ('Bat Starvation')

Flying foxes also face exposure to hazards that are part of living in an industrial society. Lead poisoning is one factor that impacted on flying foxes to a measurable degree (impacts now reduced with the widespread use of unleaded petrol). Collisions with obstacles such as airplanes, electrical wires and barbed wire are an on-going hazard (Hall and Richards 50-52). Pesticides and exposure to new bacteria may also be having an effect. 
Climate change, too, is having an impact. Flying foxes are susceptible to heat stress, and do not tolerate temperatures over about $40^{\circ} \mathrm{C}$. As Australia's heat and drought intensify under the impacts of global warming, there will be more mass deaths like the event reported in Victoria during the 2009 bushfires when the temperatures got up to about $47^{\circ}$. At least 5,000 grey-headed flying foxes died during one hot afternoon at the Yarra Bend colony ('Heat Stress' 1). This colony had already been hassled and stressed, having originally lived in the Melbourne Botanic Gardens and been forcibly shifted in 2003. There was public controversy over shifting them, and a group of volunteers have been working continuously to help the flying foxes survive in their new home. On days when the temperature is heading toward $40^{\circ} \mathrm{C}$ or more, volunteers go to the river and spray water into the trees where flying foxes are roosting.

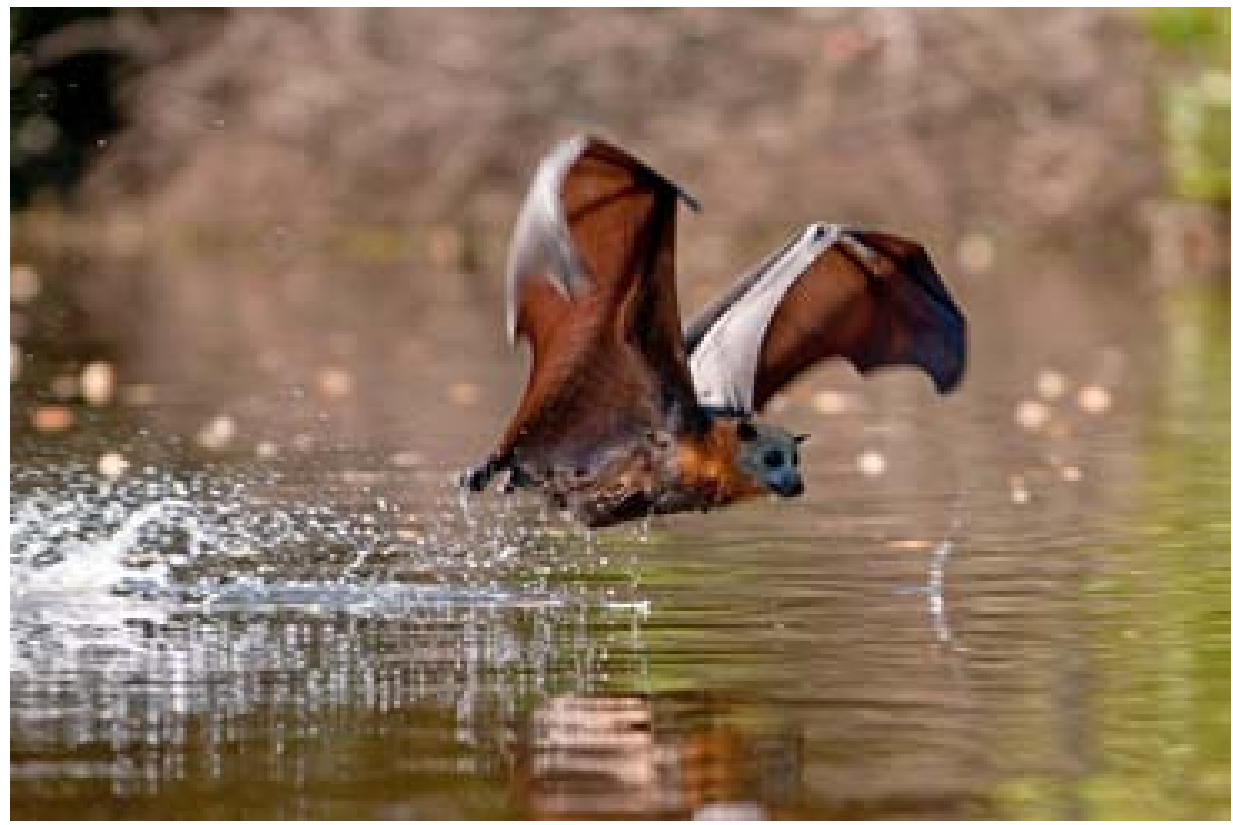

“February 8th, 2009. Parramatta Park. 40C+ and relatively low humidity gave conditions that were getting uncomfortably close to heat stress which can cause mass mortality in grey headed flying fox colonies. On the same day, thousands of greys died in heat stress conditions further south in Melbourne.

This flying fox is belly dipping in Parramatta River to rehydrate and cool herself. It's a technique that requires a lot of skill. Heat stress seems to kill a lot of very young bats and part of the reason may be that their flight skills just aren't good enough for them to belly dip"

(Photo and caption courtesy of Nick Edards).

On the other hand, even those who remain in the bush and are fully protected are still vulnerable. Another aspect of climate change is the increasing number and severity of weather 'surprises'. One such surprise was Cyclone Larry, which 
hit the Queensland coast in 2006. Along with the many banana farms destroyed, there was also damage to the rainforest; Cyclone Larry knocked down trees and land area was opened up; open land was invaded by a weed known as tobacco plant, which then attracted spectacled flying foxes. The flying foxes come in low to eat berries off the tobacco plant, and when they are that close to the ground they are prey to paralysis ticks. Other Australian mammals such as kangaroos have developed resistance to paralysis ticks, but the flying foxes are encountering them for the first time. The berries ripen at the time when mothers have recently given birth. The toxin saps the flying foxes' energy, leaving them unable to hang on to branches or care for their young. Prostrate on the ground, they die of dehydration, starvation or organ failure. A young bat who is with its mother when she is poisoned may leave the mother and fly back into the canopy, joining the others who wait for mothers who never return. According to Jenny Maclean, Director of the Tolga Bat Hospital in the Atherton Tablelands (Queensland) where much of the paralysis disaster takes place, 'we walk around the colony every day and you can hear the young bats crying for their mothers. ... Often they'll hang on for days before eventually starving to death' (qtd in Murphy). She and other volunteers, including some from the USA and the UK, collect paralysed or orphaned bats. Those that can be saved are given treatment, and when they are well enough to be let free they return to the bush. Returnees are microchipped, making them very expensive little survivors, and some microchipped flying foxes fall prey to ticks again, returning through the hospital and back to the bush more than once (Tolga Bat Hospital).

Some flying foxes have become urbanites. Like refugees everywhere, they flee the countryside because of famine, or because warfare has made life too dangerous, coming to cities in search of refuge and, perhaps, aid. In NSW, where greyheaded flying foxes are still legally (and, of course, illegally) shot, some groups have moved permanently to the city. In these urban environments the planting and watering of native trees provides a year-round food supply, streetlights aid in navigation, and they are safe from gunfire. At the same time, they are subject to urban forms of injury and death: power lines, barbed wire, garden netting and other dangers confront them (DSE 2).

Sydney's Royal Botanic Garden (SRBG) has been the occasional home for greyheaded flying foxes for many years, and that home now seems to have become permanent. The numbers rise and fall, but there is always a core group, and many of the members of the core group camp in trees that are defined as 'heritage' trees. The fact that the site is a traditional maternity camp puts constraints on the methods used to try to get them to move on. Tactics include noise harassment, and ingenious methods such as lacing trees with bundles of python excrement (olfactory deterrence: pythons are one of the main predators), and lacing trees with fermented prawn paste (taste aversion). Noise harassment is a stressful 
business for flying foxes; the equipment used in the SRBG is called the Phoenix Wailer, a computer-controlled system that blares out a variety of electronic sounds, randomly selected, to create 'a whirling effect of reverberating noises that creates a "discomfort zone"' (Richards 198-199). These methods have had the effect of getting some of flying foxes to shift, but the fact is that they are under pressure: if there is no food, they die. If living in the Botanic Gardens helps them survive during this time of land clearing, loss of myrtaceous forests and danger in the orchards, then they will try to stay. ${ }^{1}$

Direct killing has been a major factor in the loss of flying fox lives. Ratcliffe reported that in the 1920s the 'Brisbane and East Moreton Pests Destruction board' counted 300,000 flying fox deaths achieved under a bounty system (Martin and McIlwee 104). More recently, there were estimates of 100,000 or more grey-headed flying foxes being shot annually in the 1990s (Tidemann et al.).

In 1986 flying foxes were given the protection afforded to other native mammals, and could not be shot without a license, although Aboriginal people were still free to hunt them. In 2001 grey-headed flying foxes were listed as a threatened species, and licensed killing was supposed to be phased out. In 2008 the state of Queensland stopped issuing permits to kill flying foxes on the grounds that it was inhumane. At the time of writing, the state of New South Wales still issues permits to kill (Booth et al. 6). Shooting was and remains one of the primary technologies in the battle against flying foxes.

The most intense and torturous new technology of the twentieth century was electrocution. The method was to construct electric grids over orchards so that flying foxes who approached would be electrocuted. This technique was banned in Queensland after public outrage over cruelty, and a court case that tested the limits of orchardists' right to kill (Booth et al. 8). A 2007 court decision ordered orchardists who were still using grids to desist. The main grounds for the case were that the loss of spectacled flying foxes was putting the whole of the wet tropics ecosystem at risk ('Pteropus Conspicillatus').

\section{Modernity and Terror}

Ratcliffe used the language of warfare to express his mission. In his terms:

When a military commander plans an offensive he must have certain information on which to work. He needs to know, for instance, the size and strength of the enemy forces and the tactics they are likely

1 In May 2010 the Australian Federal Minster for the Environment, Peter Garrett, approved the proposal from the Royal Botanic Gardens in Sydney to disperse the flying foxes. My research has correspondingly expanded to include this event as it unfolds over the next few years. 
to employ. In the same way, before a campaign is launched against an animal enemy, it is essential to have accurate knowledge of its numbers and habits. (Ratcliffe, Flying Fox and Drifting Sand 4-5) ${ }^{2}$

Imagery of warfare can imply a two-way combat conducted according to rules. Against this imagery can be set Zygmunt Bauman's analysis of modernity's use of a narrative of future perfection to justify man-made mass death. He writes that the modern world did not do away with concepts of useless and useful, but rather set out to eliminate the 'useless'. Mass murder was imagined as 'creative destruction, conceived as a healing surgical operation' (Bauman 11).

This analysis sheds a sinister light on the idea of war against flying foxes and, indeed, war against nature more generally. From a perspective of terror, metaphors of warfare may offer a moderately positive gloss, and may thus conceal forms of lethality having more in common with mass murder than actual war. In its classic form, warfare involves an opposition of relative equals in which the matters to be determined are worked out as death and injury to the bodies of the soldiers (Scarry; Sloterdijk). The battle against flying foxes has never involved equals, and in its orientation toward extermination finds greatest affinity with modernity's terrorism.

Let us first consider the arsenal used against flying foxes as reported by Ratcliffe. In his technical report (The Flying Fox in Australia), he assessed various actions taken by orchardists against flying foxes:

- Introduced diseases - almost no chance of success (64)

- Scalp bounty system - costs more than the damage flying foxes do; least effective method (66-67)

- Poison gases (chlorine, hydrogen cyanide) in camps - ineffective (69-70)

- Explosives - 'complete failures', but could be useful if the method was to discharge shrapnel (71)

- Flame guns - costly, might be rejected on grounds of cruelty (71)

- Shooting - if organised and pursued over a number of years, might have 'beneficial effect', particularly if 'females carrying young' were targeted (72)

- Poison baits/Strychnine- -'well worth the trouble' in certain orchards (74)

Hall and Richards are blunt in their assessment that many of these methods are 'costly, often barbaric (for instance the use of flame-throwers and explosives), illogical in concept, and do not reflect well on the Australian nation' (103).

2 I have considered the possibility that Ratcliffe was being a bit tongue-in-cheek and intended this passage as a clever piece of writing that bore only tangential relationship to his work. If this is humour, it is lost on me, but perhaps in its day it made sense. I remain uncertain of the intent, but for purposes of my analysis intention is irrelevant. 
I will explore affinities between extermination, terror and lethal actions toward flying foxes, but first I must acknowledge that the problems of equating the eradication of humans with the eradication of animals is an ongoing sensitivity, discussed exquisitely in J.M. Coetzee's The Lives of Animals . At the same time, I believe that it is possible to address this comparison without cheapening anyone's life or death. My premise is that in treating human and nonhuman deaths as separate kinds of events, we miss the connectivities; we thus deprive ourselves of the capacity to understand the complexities of anthropogenic deathscapes, and have difficulty considering our entangled responsibilities and accountabilities. David Clarke has made this point in a brief and exquisite analysis in which he concludes that the disturbing comparison 'creates a rhetorical neighbourhood in which animals and humans dwell and summon each other into responsibility' (178).

The lives and deaths of flying foxes in the twentieth century show a stunning convergence between speciocide, to use Glen Mazis's term (76), and genocide. It seems that eradicating a species, or group of species, is not unlike eradicating a clan or a tribe, or undertaking ethnic cleansing. Speciocide, like genocide, may in many cases be primarily about destroying the possibility of the enemy's ongoing existence in the area you've defined as yours (whether that be a continent, a state, a region, or an orchard). Such efforts are integral to modernity's eradication of the 'useless' in the pursuit of perfection. Lethal measures are designed to free one's environment of the presence of unwanted others. To accomplish this, extermination involves terror as well as death; it involves a boundary of exclusion which will cordon off an area, keeping it 'free' of the unloved and undesired. 'Systemised terror creates a relentless climate of anguish', Sloterdijk writes (49), in words that evoke the lives and deaths of flying foxes as they are electrocuted, harassed from maternity camps, orphaned, starved, impaled on barbed wire, and otherwise subjected to direct and indirect technologies of extermination. Significantly, as well, human plans and projects of extermination follow the logic of terror - that every terrorist attack already understands itself as a counter-attack in a series initiated by the enemy (Sloterdijk 48). Thus, orchardists report themselves as under attack by plagues or infestations, and their extermination efforts are usually represented simply as self-defence.

\section{Into the Vortex}

The problem of how to connect a lethal technology with an intended target will be resolved differently depending on context, including differing target populations. One solution of the problem in relation to flying foxes appears to be unintentional, but is no less horrific for that. Martin and McIlwee work with the metaphor of a black hole in an analysis of dynamics that connect lethality with its target (105). Let us note that the term speciocide generalises. Martin and 
McIlwee offer the term pteropucide as a descriptor of the man-made mass death inflicted upon flying foxes. Their scathing analysis of attempts to eradicate flying foxes from a given area offers an understanding of why orchardists can claim that the numbers of flying foxes are increasing while scientists claim that the numbers are decreasing. Orchards (or any other places that offer food) function as a vortex that draws more and more flying foxes into it. The 'pteropucidal black hole' dynamic depends on the fact that every place which affords food and in which local populations have been eradicated entices more animals. 'The culling produces a local vacant niche, which becomes occupied by animals moving into it from further afield, which are then killed, so producing a local vacant niche which ... and so on'. They refer to such kill/attract/kill zones as pteropucidal, and they attest that the dynamic is like 'an irresistible gravitational force sweeping everything into its maw'. The inexorable dynamic works with the forces that drive flying foxes to orchards, and it creates zones of attraction which become zones of injury, suffering and death (Martin and McIlwee). At the same time, not only flying foxes themselves, but their life space is targeted; thus camps are dispersed, maternity camps are decimated, groups are harassed and stressed, groups become trapped in areas where they starve or feed on berries that bring them into peril-it goes on and on.

The metaphor of gravitational draw is powerful in itself, and can be taken further: the pteropucidal black hole does not have a boundary that stops with flying foxes. As we have seen, flying foxes are keystone species, and when they are dragged into the vortex of death, rainforests and other ecosystems are dragged along with them. This means that critically endangered ecosystems will be dragged into the vortex, and so will the rare and endangered animals who live in them - cassowaries, for example, along with a number of mammals, frogs, and other creatures. As is well known, rainforests are colloquially referred to as the 'lungs' of the planet, soaking up carbon dioxide and pumping out oxygen (Fyfe). As rainforests disappear, so does the possibility of sustaining an Earth system that will be inhabitable for large numbers of the species who have evolved here and belong here.

Of course the black hole does not exempt humans, and this is so in direct ways as well as in the prospect of losing Earth's habitable climate and atmosphere. Three significant new zoonotic viruses (transmissible between humans and animals) have emerged in flying fox populations: Hendra virus, Menangle virus and Lyssavirus. Of these, Lyssavirus is potentially the most serious in its impacts on humans; it is closely related to rabies, and has demonstrably been transmitted from a flying fox to a human. Volunteers working with flying foxes wear thick gloves and are advised to be vaccinated. It is unclear to what extent Lyssavirus may transfer to other mammal populations. 
These new viruses may have been present in flying fox populations for a long time, but have changed into active agency in recent years probably as a result of stress. Epidemiologist Hume Field explains:

It might be that wildlife populations can cope and cope and cope with impacts, until they get to a certain threshold where their ecology is fundamentally compromised. ... And it's those points ... those tipping points, that can precipitate the emergence of a new disease. (qtd in Booth et al. 17)

Flying foxes are subject to many stresses that affect their immune systems, as we have seen: harassment, dispersal, death of family members, starvation, wounding from guns and electricity as well as from hazards such as barbed wire, to recapitulate a few. The Lyssavirus is most likely to be found in animals already sick or stressed (Hall and Richards 56-57). With these emerging diseases harm has come full circle and demonstrates the inextricable connectivities between human health, flying fox health, and habitat health (Macdonald and Laurenson). And the vortex keeps growing. More stress means more illness, more illness means more people seeking to help distressed flying foxes. The language of public hygiene and biosecurity gains new force, and vilification of flying foxes gains new ammunition. As flying foxes and humans move closer and more permanently into contact with each other, so new viruses threaten both humans and flying foxes, expanding and amplifying the deathwork.

The best answer, as Booth and others point out (17), is to 'conserve flying foxes and reduce the environmental stresses-including shooting - that increase their rate of infection and the risk of spillover to other species'. If, however, the human response is to accelerate the stresses in an effort to control the boundary between humans and flying foxes, the feedback loop takes on the shape and dynamics of the death vortex. Terror returns, marking out a deathscape of disastrous, entangled, recursive and amplifying devastation.

\section{Interspecies love}

To understand one's self as part of a community of life is to accept responsibilities, and also to accept vulnerability. On a recent visit to Aboriginal communities where I had spent many years living and learning, I had a conversation with a young woman I will call Geraldine. Her father was a great flying fox storyteller, and she herself is a flying fox woman through her mother. After I had held and admired all the children, Gerry took me to the bank of the river for a chat. Every time I visit she does this - away from camp, into country, side by side looking at the river, to talk about what's happening. This time her gentle voice carried a lot of anger as she talked about what Whitefellas had done this time. They'd come through Aboriginal communities telling everybody not to touch flying foxes: 
not to eat them, not to handle them or hunt them, not to have any physical contact at all because flying fox might have disease. I could understand some of what was troubling her. Terror, it should not be forgotten, is exercised as a multispecies project. Gerry's grandfather had been shot and killed in the early days, some of her relations had been poisoned, many members of her family had seen dogs brutally shot, and dingo poisoning is a continuing feature of terrorism against animals in the region. All of them- people and their animal kin - have felt the oppressive weight of life and death decisions made elsewhere and imposed ruthlessly. This new public hygiene advice could well have looked like another round of colonising violence. That's what her tone of voice seemed to imply.

Gerry was not going along with it. 'They've been here forever', she said of her flying fox kin, 'just like us. We're not worried. They're family'.

Deborah Bird Rose is Professor of Social Inclusion in the Centre for Research on Social Inclusion at Macquarie University. Her books include Wild Dog Dreaming: Love and Extinction (2011), Country of the Heart (2nd edition, 2011), Dingo Makes Us Human (3rd edition, 2009), and Reports from a Wild Country: Ethics for Decolonisation (2004).

\section{Acknowledgements}

Thanks always to my Aboriginal teachers from whom I learned to encounter nonhuman others as sentient 'persons', some of whom were kin and almost all of whom were part of the country through Dreaming action. Thanks, too, to Les Hall who spent hours talking with me about flying foxes, primates, Lyssavirus, and other fascinating matters, and to Tim Pearson who is teaching me more than I am able to analyse in this paper. I am grateful to Nick Edards for allowing me to use his stunning photos. My research into flying foxes is currently in progress; this paper is the first entrant in the larger project. An earlier version of the paper was published in the journal Manoa (Winter 2010, issue titled: Wild Hearts: Literature, Ecology, and Inclusion).

\section{Works Cited}

'Bat Starvation Crisis in S.E. Queensland.' Bat Rescue Inc, 2006. <http://www. batrescue.org.au/index.php?option $=$ content $\&$ task $=$ view $\& i d=56 \&$ catid $=8 \&$ Itemid=10> Accessed 26 May 2009. 
'Heat Stress.' Wildlife Rescuers 1.7 (2009): 1. <http://www.wildliferescuers.org. au/Downloads/Newsletter\%20febmar2009.pdf> Accessed 26 May 2009.

'Pteropus Conspicillatus (Spectacled Flying-Fox).' Species Profile and Threats Database. Department of Sustainability, Environment, Water, Population and Communities, 2011. < http://www.environment.gov.au/cgi-bin/sprat/ public/publicspecies.pl?taxon_id=185> Accessed 4 Mar. 2011.

Bauman, Zygmunt. 'The Holocaust's Life as a Ghost.' The Holocaust's Life as a Ghost: Writings on Art, Politics, Law and Education. Ed. F.C. Decoste and Bernard Schwartz. Edmonton: U of Alberta P, 2000. 3-15.

Booth, Carol, et al. Why N.S.W. Should Ban the Shooting of Flying Foxes. Sydney: Humane Society International, 2008.

Clark, David. 'On Being 'the Last Kantian in Nazi Germany': Dwelling with Animals after Levinas.' Animal Acts: Configuring the Human in Western History. Ed. J. Ham and M. Senior. New York: Routledge, 1999. 165-98.

Coetzee, J. M. The Lives of Animals. Princeton: Princeton UP, 2001.

Conder, Pamela. With Wings on Their Fingers: An Intimate View of the FlyingFox. Sydney: Angus \& Robertson, 1994.

Department of Sustainability and Environment (DSE). 'About Flying Foxes.' (2001). <http://www.dse.vic.gov.au/dse/nrenpa.nsf/FID/-BAA86C6B029BC7 23CA256BF2001E4069?OpenDocument> Accessed 30 Jan. 2009.

Fyfe, Melissa. 'Rising Temperatures Could Spell Doom for Many of the Delicate Creatures in Queensland's Wet Tropical Rainforest.' The Age, 16 November 2005. <http://www.jcu.edu.au/rainforest/releases/the_rainforest.pdf> Accessed 5 May 2009.

Hall, Leslie, and Greg Richards. Flying Foxes: Fruit and Blossom Bats of Australia. Sydney: UNSW Press, 2000.

Haraway, Donna. When Species Meet. Minneapolis: U of Minnesota P, 2008.

Harvey, Graham. Animism: Respecting the Living World. New York: Columbia UP, 2006.

Macdonald, David, and M. Karen Laurenson. 'Infectious Disease: Inextricable Linkages between Human and Ecosystem Health.' Biological Conservation 131 (2006): 143-50.

Martin, L., and A. P. McIlwee. 'The Reproductive Biology and Intrinsic Capacity for Increase of the Grey-Headed Flying-Fox Poliocephalus (Megachiroptera), 
and the Implications of Culling.' Managing the Grey-Headed Flying-Fox as a Threatened Species in NSW. Ed. Peggy Eby and Daniel Lunney. Sydney: Royal Zoological Society of New South Wales, 2002. 91-108.

Mazis, Glen. 'The World of Wolves: Lessons About the Sacredness of the Surround, Belonging, the Silent Dialogue of Interdependence and Death, and Speciocide.' Environmental Philosophy 5.2 (2008): 69-92.

Murphy, Padraic. 'Hospital Helps Larry's Other Victims.' The Australian, 22 November 2007. <http://www.theaustralian.com.au/news/hospital-helpslarrys-other-victims/story-e6frg6oo-1111114933257> Accessed 4 Mar. 2011.

Pettigrew, John. 'Are Flying Foxes Really Primates?' Bats Magazine 3.2 (1986). $<$ http://www.batcon.org/index.php/media-and-info/bats-archives.html?tas $\mathrm{k}=$ viewArticle\&mag ArticleID=259> Accessed 4 Mar. 2011.

Ratcliffe, Francis. Flying Fox and Drifting Sand: The Adventures of a Biologist in Australia. Sydney: Angus and Robertson, 1948.

-. The Flying Fox (Pteropus) in Australia. Melbourne: Council for Scientific and Industrial Research, 1931.

Richards, G. C. 'The Development of Strategies for Management of the FlyingFox Colony at the Royal Botanic Gardens, Sydney.' Managing the Grey-Headed Flying-Fox as a Threatened Species in NSW. Ed. Peggy Eby and Daniel Lunney. Sydney: Royal Zoological Society of New South Wales, 2002. 196-201.

Scarry, Elaine. The Body in Pain: The Making and Unmaking of the World. New York: Oxford UP, 1985.

Sloterdijk, Peter. 'Airquakes.' Environment and Planning D: Society and Space 27.1 (2009): 41-57.

Tidemann, Chris, et al. 'Grey-Headed Flying Fox.' The Action Plan for Australian Bats. Ed. A. Duncan, B. Baker and N. Montgomery. Canberra: Natural Heritage Trust, 1999. 31-35.

Tolga Bat Hospital. <http://www.tolgabathospital.org/research_hospital.htm> Accessed 19 Jan. 2011. 